\title{
DNA extraction from formalin-fixed tissue: new light from the deep sea
}

\author{
FERRAN PALERO ${ }^{1}$, SALLY HALL ${ }^{2}$, PAUL F. CLARK ${ }^{3}$, DAVID JOHNSTON ${ }^{3}$, \\ JACKIE MACKENZIE-DODDS $^{3}$ and SVEN THATJE ${ }^{2}$ \\ ${ }^{1}$ Evolutionary Genetics, Institute of Science and Technology Austria (ISTA), Am Campus 1, A - 3400 Klosterneuburg, \\ Austria. E-mail: fpalero@ist.ac.at \\ ${ }^{2}$ National Oceanography Centre, Southampton, School of Ocean and Earth Science, University of Southampton, \\ European Way, Southampton, SO14 3ZH, UK. \\ ${ }^{3}$ Department of Zoology, Natural History Museum, Cromwell Road, London SW7 5BD, UK.
}

\begin{abstract}
SUMMARY: DNA samples were extracted from ethanol and formalin-fixed decapod crustacean tissue using a new method based on Tetramethylsilane (TMS)-Chelex. It is shown that neither an indigestible matrix of cross-linked protein nor soluble PCR inhibitors impede PCR success when dealing with formalin-fixed material. Instead, amplification success from formalin-fixed tissue appears to depend on the presence of unmodified DNA in the extracted sample. A staining method that facilitates the targeting of samples with a high content of unmodified DNA is provided.
\end{abstract}

Keywords: tetramethylsilane, ethidium bromide, formalin, Carcinus, Lithodidae.

RESUMEN: EXTRACCIÓN DE ADN a PARTIR DE TEJIDO FIJADO EN FORMOL: NUEVA LUZ DESDE el MAR ABISAL. - Muestras de ADN de distintos crustáceos decápodos fueron obtenidas independientemente a partir de tejidos fijados en etanol y tejidos fijados en formol mediante un nuevo protocolo basado en el Tetrametilsilano (TMS)-Chelex. Los resultados obtenidos muestran que el $\mathrm{ADN}$ no se encuentra atrapado de forma irreversible en una matriz proteica y que el éxito de amplificación no depende de la extracción de inhibidores de PCR solubles. Sin embargo, nuestros resultados indican que el éxito de amplificación depende de la presencia de ADN no modificado en la muestra. Se incluye un sencillo método de tinción que facilita la identificación de muestras con un alto contenido en ADN no modificado.

Palabras clave: tetrametilsilano, bromuro de etidio, formol, Carcinus, Lithodidae.

\section{INTRODUCTION}

Lithodids, commonly known as king crabs (Decapoda: Anomura: Lithodidae) are decapod crustaceans found in global cold and deep waters (Macpherson, 2003). Deep-sea marine specimens are expensive to collect and are rarely encountered, so that many lithodid species have been collected only once and are held as a precious resource by museums (Macpherson, 1988; Chase et al., 1998). While there is much discussion in the literature, there is no agreement on a theory of Lithodidae evolution (Cunningham et al., 1992; Thatje et al., 2005), and lack of suitable material available for molecular analysis means that theories of phy- logeny and early radiations cannot yet be fully tested (McLaughlin, 1983; Zaklan, 2002; Hall and Thatje, 2009). In order to launch a molecular phylogeny of Lithodidae, it is first necessary to obtain suitable DNA from museum specimens. However, museum material produced negative results when DNA extraction was attempted using silica-based columns (Díaz-Viloria et al., 2005).

Historically, fluid-preserved museum specimens have been initially fixed in formalin and then later transferred into alcohol or industrial methylated spirit (IMS) for archival storage (Simmons, 1995). Generally, a sodium tetraborate (borax) or sodium phosphate buffer has been used to maintain the $\mathrm{pH}$ of the formalin 
near neutrality, since buffering the formalin is essential to ensure satisfactory long-term storage of samples (Quay, 1974). In fact, many specimens prized for their morphological novelty have been kept in formalin for years (Thatje et al., 2008). Therefore, it becomes desirable to overcome barriers to molecular analysis caused by the traditional processes of preservation and considerable resources are being invested in obtaining DNA from formalin-fixed museum specimens (Scatena and Morielle-Versute, 2008; Santos et al., 2009).

Extraction and amplification of DNA from such traditionally fixed material has proven to be difficult and the reason for this is not resolved yet (France and Kocher, 1996; Gilbert et al., 2007). Several hypotheses have been proposed for explaining the difficulties found with the polymerase chain reaction (PCR), including DNA being trapped in a matrix of cross-linked proteins, severe DNA damage caused by low $\mathrm{pH}$ or the presence of PCR inhibitors in solution (Shibata, 1994; Fang et al., 2002). Many reports have been published and numerous protocols have been proposed on extraction and amplification of DNA from formalin-fixed material, but the fact remains that no reproducible and generic method has been reported to date (Diaz-Cano et al., 1997; García-Vázquez et al., 2006). Furthermore, it should be pointed out that many of these protocols are problematic, since they require multiple wash steps or long incubation periods that increase the risk of contamination (Cawkwell and Quirke, 2000; Schander and Halanych, 2003).

As a suitable starting point, the present study follows up on the latest protocols introduced in the literature to resolve the problem of DNA extraction from formalinfixed material, which are based on critical point drying (Fang et al., 2002) and Chelex (García-Vázquez et al., 2006). In order to reduce costs and provide a similar effect to that proposed in Fang et al. (2002), tetramethylsilane (TMS) will be used as a strong dehydrating agent that maintains tissue structure (Ubero-Pascal et al., 2005). Moreover, a series of investigations is set up to determine the specific way in which formalin acts to prevent amplification. Finally, tissue from both ethanol and formalin-fixed samples will be analysed in order to define a quick and inexpensive test for the validity of DNA extracts for molecular analysis.

\section{MATERIALS AND METHODS}

Thirty formalin-fixed and ten ethanol-preserved lithodid samples were extracted and amplified using a protocol based on Tetramethylsilane (TMS) (FlukaRiedel de Haën, Seelze, Germany, cat. no. 87920) and Chelex 100 resin (sodium form) (Bio-Rad, Hemel Hemstead, Herts, UK) (Fang et al., 2002). Samples were obtained from the dactylus or propodal muscle tissue of lithodid specimens in the Natural History Museum (NHM), London; the Muséum National d'Histoire Naturelle, Paris; and the Centre Mediterrani d'Investigacions Marines i Ambientals, Barcelona.
After cutting off a piece of the specimen $\left(2 \mathrm{~mm}^{3}\right)$, the tissue sample was squeezed in a piece of absorbant paper, transferred to TMS (50-100 $\mu \mathrm{l})$ and incubated with gentle agitation for $1 \mathrm{~h}$. This incubation may be carried out overnight, even though a shorter time is recommended to reduce contamination. Tissue was transferred to a new $1.5 \mathrm{ml}$ Eppendorf tube with 200 $\mu \mathrm{l}$ of $10 \%$ Chelex solution in TE $\mathrm{pH} 8.0$ and $20 \mu \mathrm{l}$ of proteinase $\mathrm{K}(20 \mathrm{mg} / \mathrm{ml}$ stock solution) and incubated for $2-3 \mathrm{~h}$ at $55^{\circ} \mathrm{C}$ in a thermomixer. Finally, the sample was centrifuged for 5-10 minutes at $10000 \mathrm{rpm}$ and 100 $\mu \mathrm{l}$ of supernatant was transferred into a fresh tube and kept at $4^{\circ} \mathrm{C}$ until used. About 1-2 $\mu \mathrm{l}$ of the supernatant was taken for each $25 \mu \mathrm{l}$ total volume PCR reaction.

Initially, a total of 3 lithodid-specific primers were designed for amplifying hemi-nested fragments of the mitochondrial $16 \mathrm{~S}$ gene region $(440 \mathrm{bp})$ using multiplex PCR (LITF1: 5'-GCCGCAGTATTTTGACTGTGCGAA-3'; LITF2: 5'-GGCTTGAATGAAAGGTTGGACAA-3' and LITR1: 5'-TCTCTTATAGCGGCTGCACCA-3'). In order to check the specificity of the primers and optimise amplification conditions, multiplex PCR was first carried out on DNA extracted from ethanol-fixed lithodid samples, and spiny lobster tissue (obtained from Palinurus elephas) was used as a negative control. Multiplex amplification reactions were carried out in a $10 \mu \mathrm{l}$ reaction containing $30 \mathrm{ng}$ of genomic DNA, 0.5x QIAGEN Multiplex PCR Kit 2x and $0.2 x$ of equimolar $(1 \mathrm{mM})$ primer mix. The PCR thermal profile used was $94^{\circ} \mathrm{C}$ for $4 \mathrm{~min}$ for initial denaturation, followed by 30 cycles of denaturation at $94^{\circ} \mathrm{C}$ for $30 \mathrm{~s}$, annealing temperature at $54^{\circ} \mathrm{C}$ for 30 $\mathrm{s}$, extension at $72^{\circ} \mathrm{C}$ for $30 \mathrm{~s}$, and a final extension at $72^{\circ} \mathrm{C}$ for $4 \mathrm{~min}$. The PCR reaction was loaded to a $1 \%$ agarose gel in TBE with EtBr together with HyperLadder I and HyperLadder IV (Bioline). Sequences were obtained using the Big-Dye Ready-Reaction kit v3.1 (Applied Biosystems, Foster City, USA) on an ABI Prism 3770 automated sequencer from the Molecular Biology Unit, NHM.

To examine the effect of formalin on the process of DNA liberation from tissue, a $30 \mathrm{~h}$ time-series proteinase $\mathrm{K}$ digestion (proteinase $\mathrm{K}$ from Tritirachium album, Roche Diagnostics GmbH, Mannheim, Germany) of both formalin-fixed $(\mathrm{n}=8)$ and control ethanol-fixed $(n=4)$ samples was carried out. The amount of DNA in solution (ng/ $\mu \mathrm{l})$ was measured using a NanoDrop ${ }^{\mathrm{TM}}$ 1000 Spectrophotometer (Thermo Fisher Scientific) at several time intervals. Secondly, in order to attempt to eliminate the effect of soluble PCR inhibitors, both physical (filtering) and chemical DNA cleaning techniques were applied to the Chelex-extracted DNA. Therefore, two different filtering systems provided by Millipore, namely the 96-well MultiScreen plates (Cat. MAPBMN310) together with a MultiScreen ${ }^{\mathrm{TM}}$ Vacuum Manifold, and the Microcon columns (YM100) used with a Microcentrifuge (Eppendorf Model 5415D, VWR Int Ltd, Poole Dorset, UK) were applied to the crude DNA extract following the manufacturer's 
guidelines (http://www.millipore.com/userguides/). The chemical-based DNA cleaning techniques were used in separate treatments of genomic extracts prior to PCR amplification. Both Phenol: Chloroform: Isoamyl alcohol purification (Sigma-Aldrich cat. P2069, Dorset, UK) and Isopropanol precipitation methods were carried out following the standard protocols included in Sambrook et al. (1989).

In addition, and in order to confirm the validity of a simple test for predicting PCR success, a total of 88 Carcinus samples collected from different localities were analysed. From these, 66 samples were obtained from NHM collections (Sandy Bay and Europa Point, Gibraltar and Ebro Delta, Spain; Clark et al., 2001) and 12 samples were obtained from recent ethanol-fixed material (Cullera, Spain; present study). Multiplex amplification reactions were carried out as previously stated but using Folmer et al. (1994) (LCO1490: 5'-GGTCAACAAATCATAAAGATATTGG-3'; HCO2198: 5' -TAAACTTCAGGGTGACCAAAAAATCA-3') and Darling et al. (2008) (COIF-PR115: 5'-TCWACNAAYCAYAARGAYATTGG-3'; COIR-PR114: 5'-ACYTCNGGRTGNCCRAARARYCA-3') mitochondrial cytochrome oxidase I (COI) primers at $45^{\circ} \mathrm{C}$ annealing temperature for $30 \mathrm{~s}$. A one-side Fisher's exact probability test was carried out on the PCR success/failure table for the green/orange DNA as implemented in the function fisher.test of the stats package in R v2.9.1 (R Development Core Team, 2009). Fisher's exact probability test is recommended in order to test for differences in success rates from two-by-two contingency tables with moderate sample sizes (Martín Andrés et al., 2004).

\section{RESULTS}

Of the thirty formalin-fixed lithodid tissue samples analysed, 18 failed to produce 16S PCR products, 5 produced amplicons but were not successfully sequenced, and 7 samples with band sizes of 250-300 bp produced fully-sequenced PCR products (GenBank accession numbers: EU493266, EU493268-72 and EU493275). Moreover, all 10 ethanol-preserved lithodid samples produced fully-sequenced PCR products (GenBank accession numbers: EU493267, EU493273-74, EU493276-EU493278, FJ462644-45 and FJ462648). A database search in GenBank using Megablast (BLASTN v2.2.18) showed that sequences from formalin-fixed specimens were homologous to available lithodid sequences. Sequences from formalin-fixed samples were either closer to those obtained from species with similar geography and morphology, or they matched exactly with sequences that had been independently obtained from fresh specimens of the same species in other laboratories. For example, two specimens of Paralomis cristata (Takeda and Ohta, 1979) included in the present study correspond to one specimen preserved in formalin in 1987 and analysed in NHM (EU493266), and another sequence independ-

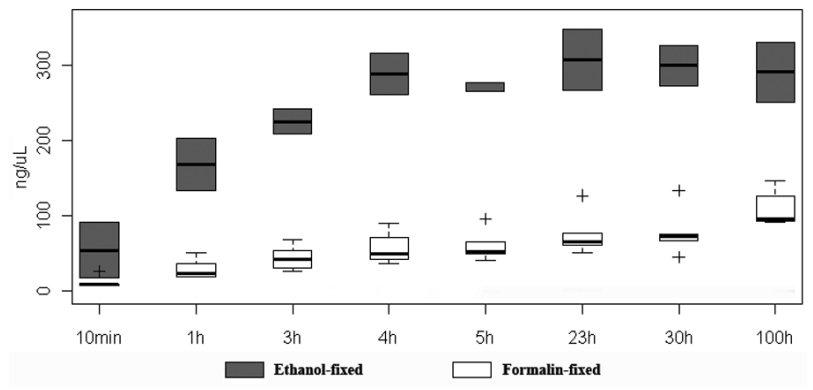

FIG. 1. - Time course of proteinase K-induced release of DNA obtained from formalin-fixed samples and from ethanol-fixed controls as measured by NanoDrop spectrophotometry.

ently obtained in Germany by S. Hall from an ethanol-fixed sample (EU493267). Moreover, one of the successful samples from this study, Lithodes turkayi Macpherson, 1988 (NHM registration no. 2004.2994; GenBank code: EU493268) had been kept in formalin continuously since its fixation in 1932 .

The results obtained from the proteinase $\mathrm{K}$ timeseries digestion experiment indicate that DNA can be released from formalin-fixed tissue (Fig. 1). Furthermore, gel electrophoresis of extracted DNA showed that despite increased DNA degradation in formalinfixed samples, fragments larger than $1 \mathrm{~Kb}$ can still be found in formalin-fixed specimens (Fig. 2A). Nevertheless, the presence of large fragments of DNA could not be taken as an effective predictor of PCR success, since none of the four cleaning protocols tested (Millipore MultiScreen plates, Microcon columns (YM-100), Phenol: Chloroform: Isoamyl alcohol purification, and Isopropanol precipitation) gave positive 16S PCR results for those samples that had failed when processed directly from the Chelex extraction supernatant. In fact, our results from lithodid samples pointed out that rather than overall DNA fragment size, it was DNA staining behaviour that could be used as an effective predictor of PCR success.

In order to confirm the validity of our staining protocol for predicting PCR success from genomic DNA, two sets of ethanol-fixed (12) and formalin-fixed (66) Carcinus samples were analysed. After running $5 \mu \mathrm{l}$ of DNA-Chelex supernatant on a $1 \%$ agarose gel and staining with ethidium bromide, the gel was photographed under UV light (250-360 nm) (Fig. 2A). This simple test identified two different types of extracted DNA; while PCR-negative samples only contained green autofluorescent material, both green autofluorescent and ethidium bromide-stained orange DNA could be observed on PCR-positive samples. When ethanolpreserved tissue from fresh specimens is analysed using this method, only ethidium bromide-stained orange DNA is observed (Fig. 2A). In fact, NHM Carcinus samples containing orange DNA yielded a considerably larger proportion of successes (9.2 times more success) than samples containing just green DNA. From 66 formalin-fixed NHM Carcinus samples, those with orange DNA provided a larger number of PCR 


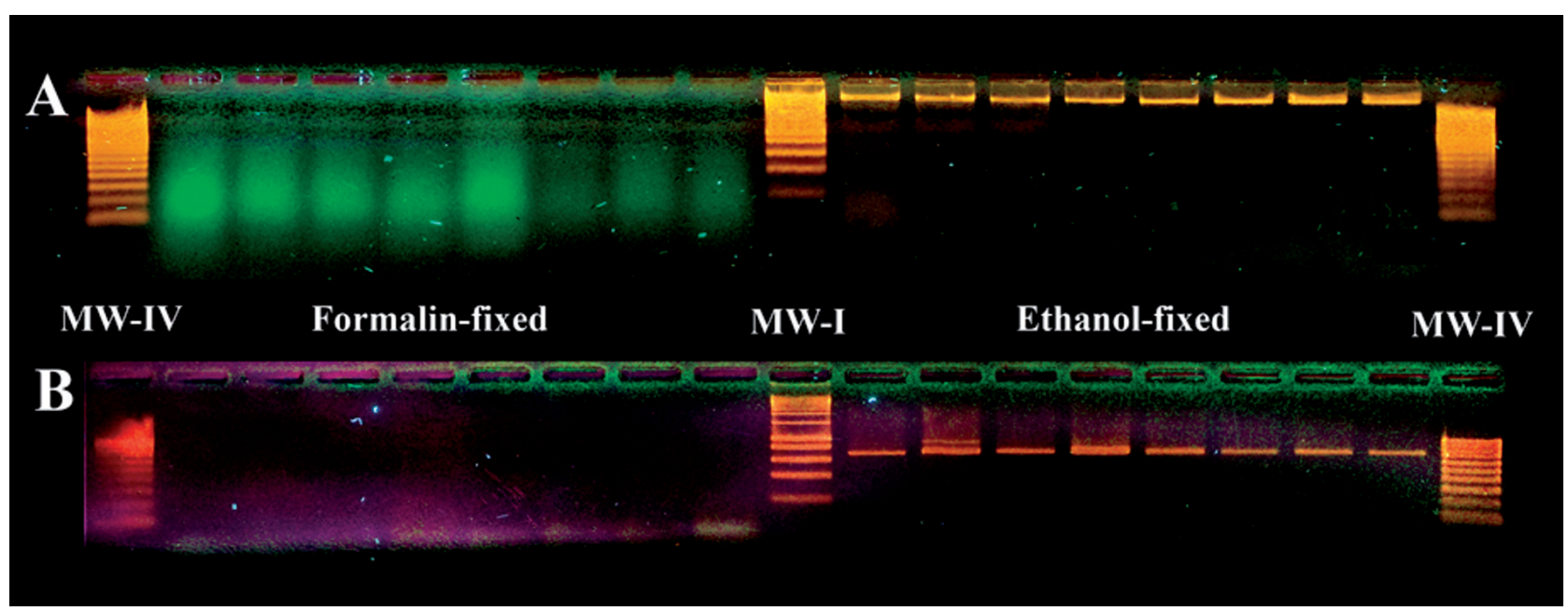

FIG. 2. - Different staining behaviour and PCR success of the COI gene from DNA obtained from formalin and ethanol-fixed material. Agarose gel analysis of (A) $5 \mu \mathrm{l}$ of Chelex supernatant and (B) $3 \mu \mathrm{l}$ of PCR amplicon ( 640 bp) is presented. MW-I = DNA HyperLadder I; MW-IV = DNA HyperLadder IV. HyperLadder IV produces a pattern of 9 regularly spaced bands, ranging from 100 to 1000 bp.

bands (18) than negative results (10), while most samples with green DNA failed to amplify (32) and just 6 produced PCR bands (Fig. 2B). This difference in COI PCR success between formalin-fixed samples containing green DNA only and those containing green and orange DNA was found to be significant according to Fisher's exact probability test $(\mathrm{p}<0.01)$. All 12 ethanolfixed Carcinus samples from Cullera provided positive results.

\section{DISCUSSION}

While previous studies using oligonucleotides or isolated DNA have described the presence of lesions in DNA exposed to formaldehyde (Huang and Hopkins, 1993), the present study indicates that, even though only $24 \%$ of lithodid samples gave positive results, fully reliable sequence data can still be retrieved from formalin-fixed museum specimens. The comparison of sequence data from formalin-fixed samples and fresh and ethanol preserved specimens collected at independent laboratories for the same species (i.e. Paralomis granulosa from Zaklan, 2002) confirms the validity of sequences obtained from formalin-fixed material. In other cases we have been able to compare sequence data from closely related species belonging to the same genus (i.e. Paralomis africana and Paralomis granulosa). Moreover, although the TMS-Chelex protocol is reported for the first time in this validation study, it has been used previously with success on formalin-fixed spiny lobster specimens from the National Museum of Natural History, Washington (Palero et al., 2009).

Among the most interesting results from this validation study, it is worth pointing out that none of the four cleaning protocols tested had a measurable effect on amplification success, which suggests that either no direct PCR inhibitor is present in the solution, or it could not be removed by these techniques. PCR inhibition did not seem to be caused by DNA shear- ing either, since positive results were obtained from museum samples with sheared-DNA. Therefore, by using a quick and inexpensive test on both successful and failed DNA extracts from formalin-fixed samples, it was inferred that green-stained material on the agarose gel corresponds to DNA molecules that have been modified by formalin (and are therefore unsuitable as PCR templates), while orange-stained material corresponds to unmodified DNA molecules (which can be used as functional PCR templates).

The results obtained in the present study indicate that formalin does directly modify DNA molecules themselves and impedes PCR without the need for other PCR inhibitors or protein complexes. These observations agree with predictions made by Chaw et al. (1980) concerning cross-link interactions among amino groups of nucleosides from DNA. Indeed, amplification success did not depend on digestion time, since DNA extracts from successful samples showed PCR band amplification after 1-3 h digestion while non-successful samples did not amplify irrespectively of the incubation time (results not shown). It is well known that PCR is sensitive enough to provide a million copies of a target DNA sequence from only a few molecules (Saiki et al., 1988), so that it seems reasonable to expect positive results from formalin-fixed samples for which some unmodified DNA is still available. Therefore, the presence of unmodified DNA molecules in the samples analysed could explain the positive results for many (if not all) of the protocols previously proposed (Fang et al., 2002; García-Vázquez et al., 2006).

Obtaining DNA sequences from specimens that have been initially fixed in formalin is not a straightforward task and more work is required to optimise methodologies, and reduce costs and handling times (Schander and Halanych, 2003). Indeed, the present study does not claim that a final solution has been found for any formalin-fixed tissue. Nevertheless, this study shows that it is possible to obtain reliable and in- 
formative sequence data from formalin-fixed samples and presents an easy-to-use diagnostic test to assess the suitability of DNA extracts for molecular analysis. Factors such as $\mathrm{pH}$ and temperature can modify the effects of formalin fixation on DNA (Chang and Loew, 1994; Shi et al., 2004) and it is possible that some unmodified DNA is still available in formalin-fixed samples preserved many years ago. The fact that this inexpensive method can be used as a simple and direct test for DNA modification in multiple samples, provides the opportunity for future studies to screen several tissues and select those most suitable for use in molecular analyses while optimising resources for PCR amplification and sequencing.

\section{AKNOWLEDGEMENTS}

The authors would like to thank two anonymous reviewers for their remarks, which helped to improve the manuscript. This project was supported by the Marine Biodiversity and Ecosystem Functioning Network of Excellence MarBEF (Contract no. GOCECT-2003-505446) of the $6^{\text {th }}$ European Framework Programme (FP6), the Zoology Research Fund, Department of Zoology, NHM, London, a Research Grant from the Royal Society to S.T., and a pre-doctoral fellowship awarded by the Autonomous Government of Catalonia to F.P. (2006FIC-00082). This research received support from the SYNTHESYS Project http://www.synthesys. info/ which is financed by European Community Research Infrastructure Action under the FP6 "Structuring the European Research Area" Programme. Many thanks are due to J. Fortuño for suggesting TMS as an alternative to critical point drying, P. Crabb for helping with the UV-light photography setting and our colleagues/friends in the Whale Basement Molecular Laboratories, Department of Zoology NHM

\section{REFERENCES}

Cawkwell, L. and P. Quirke. - 2000. Direct multiplex amplification of DNA from a formalin fixed, paraffin wax embedded tissue section. J. Clinic. Pathol. Mol. Pathol., 53: 51-52.

Chang, Y. and G. Loew. - 1994. Reaction mechanisms of formaldehyde with endocyclic imino groups of nucleic acid bases. J. Am. Chem. Soc., 116: 3548-3555.

Chase, M., R. Etter, M. Rex and J. Quattro. - 1998. Extraction and amplification of mitochondrial DNA from formalin-fixed deepsea mollusks. Biotechniques, 24: 243-247.

Chaw, Y., L. Crane, P. Lange and R. Shapiro. - 1980. Isolation and identification of cross-links from formaldehyde-treated nucleic acids. Biochemistry, 19: 5525-5531.

Clark, P.F., M. Neale and P.S. Rainbow. - 2001. A morphometric analysis of regional variation in Carcinus Leach, 1814 (Brachyura: Portunidae: Carcininae) with particular reference to the status of the two species C. maenas (Linnaeus, 1758) and $C$. aestuarii (Nardo, 1847). J. Crustac. Biol., 21: 288-303.

Cunningham, C., N. Blackstone and L. Buss. - 1992. Evolution of king crabs from hermit crab ancestors. Nature, 355: 539-542.

Darling, J.A., M.J. Bagley, J. Roman, C.K. Tepolt and J.B. Geller. 2008. Genetic patterns across multiple introductions of the globally invasive crab genus Carcinus. Mol. Ecol., 17: 4992-5007.

Diaz-Cano, S. and S. Brady. - 1997. DNA extraction from formalinfixed, paraffin-embedded tissues: Protein digestion as a limiting step for retrieval of high-quality DNA. Diagn. Mol. Pathol., 6:
342-346.

Díaz-Viloria, N., L. Sánchez-Velasco and R. Pérez-Enríquez. 2005. Inhibition of DNA amplification in marine fish larvae preserved in formalin. J. Plankton Res., 27: 787-792.

Fang, S., Q. Wan and N. Fujihara. - 2002. Formalin removal from archival tissue by critical point drying. Biotechniques, 33: 604-611.

Folmer, O., M. Black, W. Hoeh, R. Lutz and R. Vrijenhoek. - 1994. DNA primers for amplification of mitochondrial cytochrome c oxidase subunit I from diverse metazoan invertebrates. Mol. Mar. Biol. Biotech. 3: 294-299.

France, S. and T. Kocher. - 1996. DNA sequencing of formalinfixed crustaceans from archival research collections. Mol. Mar. Biol. Biotech., 5: 304-313.

García-Vázquez, E., P. Alvarez, P. Lopes, N. Karaiskou, J. Perez, A. Teia, J.L. Martinez, L. Gomes and C. Triantaphyllidis. - 2006. PCR-SSCP of the 16S rRNA gene, a simple methodology for species identification of fish eggs and larvae. Sci. Mar., 70S2: 13-21.

Gilbert, M.T.P., T. Haselkorn, M. Bunce, J.J. Sanchez, S.B. Lucas, L.D. Jewell, E. van Marck and M. Worobey. - 2007. The isolation of nucleic acids from fixed, paraffin-embedded tissues - which methods are useful when? PLOS ONE, 2(6): e537. doi:10.1371/journal.pone.0000537.

Hall, S. and S. Thatje. - 2009. Global bottlenecks in the distribution of marine Crustacea: temperature constraints in the family Lithodidae. J. Biogeogr., 36: 2125-2135.

Huang, H. and P. Hopkins. - 1993. DNA interstrand cross-linking by formaldehyde: Nucleotide sequence preference and covalent structure of the predominant cross-link formed in synthetic oligonucleotides. J. Am. Chem. Soc., 115: 9402-9408.

Macpherson, E. - 1988. Revision of the family Lithodidae Samouelle, 1819 (Crustacea: Decapoda: Anomura) in the Atlantic Ocean. Mon. Zool. Mar., 2: 9-153.

Macpherson, E. - 2003. Some lithodid crabs (Crustacea: Decapoda: Lithodidae) from the Solomon islands (SW Pacific Ocean) with the description of a new species. Sci. Mar., 67: 413-418.

Martín Andrés, A., A. Silva Mato, J.M. Tapia García and M.J. Sánchez Quevedo. - 2004. Comparing the asymptotic power of exact tests in $2 \times 2$ tables. Comp. Stat. \& Data Anal., 47(4): 745-756.

McLaughlin, P. - 1983. Hermit crabs - are they really polyphyletic? J. Crustac. Biol., 3: 608-621.

Palero, F., K.A. Crandall, P. Abelló, E. Macpherson and M. Pascual. - 2009. Phylogenetic relationships between spiny, slipper and coral lobsters (Crustacea: Decapoda: Achelata). Mol. Phylogenet. Evol., 50: 152-162.

Quay, W. - 1974. Bird and mammal specimens in fluid-objectives and methods. Curator, 17: 91-104.

R Development Core Team. - 2009. R: A language and environment for statistical computing. R Foundation for Statistical Computing, Vienna, Austria. ISBN 3-900051-07-0, URL http:// www.R-project.org

Saiki, R., D. Gelfand, S. Stoffel, S. Scharf, R. Higuchi, G. Horn, K. Mullis and H. Erlich. - 1988. Primer-directed enzymatic amplification of DNA with a thermostable DNA polymerase. Science, 239: 487-491.

Sambrook, J., E. Fritsch and T. Maniatis. - 1989. Molecular cloning: A laboratory manual. Cold Spring Harbor Laboratory, New York.

Santos, S., D. Sá, E. Bastos, H. Guedes-Pinto, I. Gut, F. Gärtner and R. Chaves. - 2009. An efficient protocol for genomic DNA extraction from formalin-fixed paraffin-embedded tissues. Res. Vet. Sci., 86: 421-426.

Scatena, M. and E. Morielle-Versute. - 2008. Suitability of DNA extracted from archival specimens of fruit-eating bats of the genus Artibeus (Chiroptera, Phyllostomidae) for polymerase chain reaction and sequencing analysis. Gen. Mol. Biol., 31: 160-165.

Schander, C. and K. Halanych. - 2003. DNA, PCR and formalinized animal tissue - a short review and protocols. Org. Diver. Evol., 3: $195-205$.

Shi, S., R. Datar, C. Liu, L. Wu, Z. Zhang, R. Cote and C. Taylor. - 2004. DNA extraction from archival formalin-fixed, paraffinembedded tissues: Heat-induced retrieval in alkaline solution. Histochem. Cell Biol., 122: 211-218.

Shibata, D. - 1994. Extraction of DNA from paraffin-embedded tissue for analysis by polymerase chain-reaction - new tricks from 
an old friend. Human Pathol., 25: 561-563.

Simmons, J. - 1995. Storage in fluid preservatives. In: C. Rose, C. Hawks and H. Genoways (eds.), Storage of natural history collections: A preventive conservation approach, pp. 161-186. Society for the Preservation of Natural History Collections, Iowa.

Takeda, M. and Y. Ohta. - 1979. A new species of Lithodidae from Suruga Bay, central Japan. Bull. Natl. Sci. Mus. A, 5: 195-200.

Thatje, S., K. Anger, J. Calcagno, H. Lovrich, H. Pörtner and W. Arntz. - 2005. Challenging the cold: Crabs reconquer the Antarctic. Ecology, 86: 619-625

Thatje, S., S. Hall, C. Hauton, C. Held and P.A. Tyler. - 2008. Encounter of lithodid crab Paralomis birsteini on the continental slope off Antarctica, sampled by ROV. Polar Biol., 31: 1143-1148.

Ubero-Pascal, N., J. Fortuño and M. Puing. - 2005. New applica- tion of air-drying techniques for studying Ephermeroptera and Plecoptera eggs by scanning electron microscopy. Micr. Res. Tech., 68: 264-271.

Zaklan, S. - 2002. Review of the family Lithodidae (Crustacea: Anomura: Paguroidea): Distribution, biology and fisheries. In: A. Paul, E. Dawe, R. Elner, G. Jamieson, G. Kruse, R. Otto, B. Sainte-Marie and T. Shirley (eds.), Crabs in cold water regions: Biology, management and economics, pp. 58-84. Alaska Sea Grant College Program, Fairbanks.

Scient. ed.: J. Viñas.

Received December 12, 2008. Accepted November 3, 2009.

Published online May 14, 2010. 